\title{
Profile of nursing professionals assisted by a multidisciplinary mental health team
}

\author{
Perfil de trabalhadores de enfermagem acompanhados por equipe multiprofissional de \\ saúde mental
}

\section{Perfil de trabajadores de enfermería acompañados por grupo de atención al paciente en salud mental}

Gleide Santos de Araújo ${ }^{1}$, Aline Santos Sampaio ${ }^{1}$, Edna Moreira dos Santos ${ }^{1}$, Suely Maia Galvão Barreto ${ }^{1}$, Nilton José Vitório Almeida ${ }^{1}$, Maria Luiza Dias dos Santos ${ }^{1}$

The present study aims at investigating the profile of nursing professionals assisted by the multidisciplinary mental health team. This is a quantitative study with 385 records of workers who were attended the university medical service by a team of mental health from July 2009 to December 2010, the averages were calculated using the chi-square test and with level of significance of $5 \%(\mathrm{p}<0.05)$. It was observed that nursing professionals had, in the average, lower age $(47.5 \pm 9.7)$, more absences $(5.15 \pm 3.29)$ and were more days away from work $(191.8 \pm 168.5)$ compared to other categories, respectively (53.7 \pm 12.7$),(2.18 \pm 2.8)$ and $(138 \pm 163)$. The majority was diagnosed with affective and mood disorders $(65 \%)$ and they were prescribed controlled medicine (96.8\%), the differences were statistically significant in relation to other professionals. Although younger, the nursing staff stayed away longer, more frequently and had more mental health problems.

Descriptors: Nursing; Mental Health; Occupational Health.

Objetivou-se identificar o perfil de trabalhadores de enfermagem de uma universidade federal acompanhados pela equipe multiprofissional de saúde mental. Estudo quantitativo, com 385 prontuários de trabalhadores atendidos no serviço médico da universidade pela equipe de saúde mental entre julho de 2009 e dezembro de 2010. Foram calculadas as médias, quiquadrado e nível de significância de $5 \%(\mathrm{p}<0,05)$. Observou-se que trabalhadores de enfermagem possuíam em média menor idade $(47,5 \pm 9,7)$, mais afastamentos $(5,15 \pm 3,29)$ e permaneciam mais dias afastados $(191,8 \pm 168,5)$ em comparação aos de outras categorias, respectivamente $(53,7 \pm 12,7),(2,18 \pm 2,8)$ e $(138 \pm 163)$. A maioria possuía diagnóstico de transtornos afetivo e de humor (65\%) e indicação médica para uso de medicação controlada $(96,8 \%)$, diferença estatisticamente significante em relação aos demais. Apesar de mais jovens, trabalhadores de enfermagem afastaram-se por mais tempo, em maior frequência e apresentaram mais problemas de saúde mental.

Descritores: Enfermagem; Saúde Mental; Saúde do Trabalhador.

El objetivo fue investigar el perfil de trabajadores de enfermería de una universidad federal acompañados por grupo de atención al paciente en salud mental. Estudio cuantitativo, con 385 registros médicos de trabajadores atendidos en el servicio médico de la universidad por el equipo de salud mental, entre julio de 2009 y diciembre de 2010. Fueron calculados las medias, Chi-cuadrado y el nivel de significancia de $5 \%(\mathrm{p}<0,05)$. Se observó que trabajadores de enfermería tenían en media menor de edad $(47,5 \pm 9,7)$, más alejamientos $(5,15 \pm 3,29)$ y permanecían más días alejados $(191,8 \pm 168,5)$ en comparación a las otras categorías, respectivamente $(53,7 \pm 12,7),(2,18 \pm 2,8)$ y $(138 \pm 163)$. La mayoría tenían diagnóstico de trastornos afectivo y de humor (65\%) e indicación médica para uso de medicación controlada (96,8\%), diferencia estadísticamente significantes en relación a los otros profesionales. Aunque muy jóvenes, trabajadores de enfermería se alejaron por más tiempo, con mayor frecuencia y presentaron más problemas de salud mental.

Descriptores: Enfermería; Salud Mental; Salud Laboral.

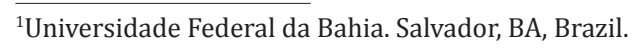




\section{Introduction}

The assistance to the needs for living is not the only thing men look for at work, but also his personal valuing and satisfaction as a useful human being provided with intellectual capacity. Thus, at work, physical and psychic aspects are directly related and can both represent balance and satisfaction, as well as cause tension, misfit and sickening. The relation between work and health/disease has not always constituted a focus of attention. However, it is known that the mental and behavior disorder related to work occur due to several factors such as the exposition to some toxic chemical agents, as well as the factor related to the organization of the work, hierarquical organization of the structure and condition of work ${ }^{(1)}$.

The mental disorders are alterations in the functioning of the mind which jeopardize the work of a person, and they do not leave any aspect of the human condition untouched. They occupy the third position among the causes of pension due to diseases, keeping him away from the work for more than 15 days and pension for permanent disability. The ones who are minors represent around $30 \%$ of the workers and the severe cases represent from $5 \%$ to $10 \%{ }^{(2)}$. The vulnerability to get sick at work is not homogenously distributed, it depends among other factors, on the requirements to which the worker is submitted when doing his professional activity and on the psychological resources available for him to face such adversities.

Considering that the possibility of getting a psychic disorder related to work is not similar among the other existing professional activities, some categories of workers experience suffering and conflicts at work more intensively compared to others. The nursing professionals besides constituting the largest category of workers in the area of health, they are more exposed to conflicting situation, overload, stress, instability and pressures experienced when exercising their profession; problems which can be consider determinant for the process health-disease of these workers ${ }^{(3)}$.

Such category is pointed as one of the most stressing by the International Labour Organization (ILO), and that is why it is objective of studies, however there are scarce researches on the psychic sickness of these professionals and associated factors ${ }^{(4)}$. The nursing professionals with numberless wearing circumstances present in their daily activities, their labor environment can provide psychic disorders for these workers who deal with diseases and suffering of others, render interrupted health care 24 hours a day, executing sequences of stressing and bureaucratic activities $^{(5)}$.

Besides that, the nursing professionals keep contact with a variety of physical, chemical, biological, ergonometric risks, as well as the ones caused by accidents, which impose them situations which can lead them to psychic disorder. Among the main factors of demotivation and suffering there are: low pay, double shift of work, precarious conditions of work, both in private institutions as well in public ones ${ }^{(6)}$. Furthermore, nursing has been historically associated to marginalization, professional devaluation and low social recognition, which lead the workers to constantly pursuit their professional satisfaction ${ }^{(3)}$.

In the public services, despite a certain comfort due to stability at work, the nursing professionals also face difficulties, such as the precarious conditions of work, overload, decrease of professional autonomy, weakening of professional recognition, long time spent with bureaucratic tasks and pressure, both from hierarchy as well as from the users, which can generate a feeling of impotence concerning the quality of assistance to the user, stress and dissatisfaction. Therefore, the public administration can contribute for the sickening-work leave process and neglecting the attention to the health of the worker ${ }^{(7)}$.

So, the present investigation is justified by the need to enhance the knowledge concerning problems of mental health among nursing professionals, including the main causes for psychic disorder, absenteeism, clinical and demographic characteristics 
of this population, matters whose possibilities of study were not yet sufficiently explored. Facing the above considerations, the objective is to identify the profile of the nursing professionals of a federal university assisted by a multiprofessional team of mental health.

\section{Method}

It is a descriptive, exploratory, documental study, with quantitative approach. Document here means any support which contains registered information, forming a unit which can be used as reference, study or evidence, such as publishings, manuscripts and registers without modifications ${ }^{(8)}$. The study is included in a wider research developed by the group of mental health of a health unit which is a part of the Subsistema Integrado de Atenção à Saúde do Servidor (Integrated Subsystem of Attention to the Health of the Worker) (SIASS), whose aim is to coordinate and provide actions and programs in the areas of official expert medical report, surveillance, promotion, prevention and assistance of the workers of the direct autarchic and foundational federal administration ${ }^{(9)}$. The data of the wider study were concerning the population of workers, their dependence, retired workers, students linked to the federal university and a small parcel of people who are not linked to the teaching institution, once they were registered by the mental health team of the investigated service, corresponding to 990 medical registers. The medical records which did not have information on international classification of diseases (ICD-10) were excluded.

A sample included all the medical records of the workers of that university, with registers on medical assistance by the mental health team of the investigated medical service, there were 385 (38.9\%) health professionals, of those 93 (24.1\%) were nursing workers.

Data extract from medical records of patients assisted by a psychiatrist of the multiprofessional mental health team of the unit in which the study occurred from July 2009 to December 2010. Data collection occurred from March to December, 2012. A standard form was used, which included questions on the data of identification of the units where the workers belonged, as well as occupational, socio-demographic and clinical information. The occupational variables were the professional category which the worker belonged to, number of working leaves and number of days the worker was away. The social demographic variables were age and gender. The ones referring to the clinical situation were the category of the health professional chosen for appointment, medical indication of the use of controlled medicine and code of the International Classifications of Diseases (ICD).

An exploratory analysis was made to evaluate the distribution and characteristics of the variables, presence of absent data, also inconsistent data for the necessary corrections and descriptive analysis in order to characterize the population of the study and profile of the nursing workers according to the sociodemographic, clinic and occupational variables.

The chi-square test was used to verify the differences among the groups, using $\mathrm{p}$ value higher than 0.05. The Epi info program was used in the data collection and the Stata version 10 throughout the process of data analysis. The study was made according to the guidelines and rules for researches involving human beings, submitted to the Committee of Ethics of the University Hospital of Universidade Federal da Bahia with the approval number 114/2008. The information of the patients was kept in secret in all the stages of the study under the responsibility of the team involved in the making of the research.

\section{Results}

The average of the age of the nursing professionals was lower regarding the workers of other categories investigated: 47.5 years ( $S D=9.7$ ). Followed by professors, 51.2 years $(\mathrm{SD}=12.4)$ and other workers 53.7 years $(\mathrm{SD}=12.7)$. 
Table 1 - Average of age and number of working leaves of the workers of the federal university, according to their professional category

\begin{tabular}{lccc}
\hline Function & Observations & Average & Standard Deviation \\
\hline Nursing & 93 & 47.5 & 9.7 \\
Professor & 53 & 51.2 & 12.4 \\
Others & 231 & 53.7 & 12.7 \\
\hline
\end{tabular}

The average of working leaves in the period of the study was inverse, higher among the nursing professional with 5.15 leaves $(\mathrm{SD}=3.29)$, followed by others professions 3.03 working leaves $(\mathrm{SD}=2.8)$. The professors had the lowest average of leaves, 2.18 $(\mathrm{SD}=2.8)$.

Table 2 - Average of the number of working leaves of the workers of the federal university, according the Professional category

\begin{tabular}{lcccc}
\hline Function & Observations & Average (SD)* & Min. & Max. \\
\hline Nursing & 78 & $5.15(3.3)$ & 1 & 13 \\
Professor & 33 & $2.18(2.8)$ & 1 & 12 \\
Other & 154 & $3.03(2.8)$ & 1 & 22 \\
\hline *Standard Deviation & & & &
\end{tabular}

The average of leaves in the two investigated years was higher among the nursing professionals: 191.8 days $(\mathrm{SD}=168.5)$.

Table 3 - Average of days of working leaves of workers of the federal university, according to the professional category

\begin{tabular}{lcccc}
\hline Function & Observations & Average (SD)* & Min. & Max. \\
\hline Nursing & 78 & $191.8(168.5)$ & 5 & 578 \\
Professor & 33 & $157.9(146.7)$ & 1 & 520 \\
Others & 154 & $138.0(163.0)$ & 1 & 985 \\
\hline
\end{tabular}

There is a statistically significant difference among the nursing professionals and the other categories regarding the medical diagnosis according to the ICD. For the nursing professionals the most prevalent disorders were the ones concerning effectiveness and humor, 54 patients (51.1\%), behavioral syndromes with physiological disorders, $21(22.6 \%)$.
Table 4 - International Classification of Diseases regarding the working leaves of the federal university workers

\begin{tabular}{|c|c|c|c|}
\hline \multirow[b]{2}{*}{ Mental Health Problems } & \multicolumn{3}{|c|}{ Nursing professional } \\
\hline & $\begin{array}{c}\text { Yes } \\
\mathrm{n}(\%)\end{array}$ & $\begin{array}{l}\text { No } \\
\text { n (\%) }\end{array}$ & $\mathrm{p}$ value \\
\hline Mental Organic Diseases & $00(0.0)$ & $9(3.8)$ & \\
\hline $\begin{array}{l}\text { Mental diseases resulting from } \\
\text { the use of psycho - active } \\
\text { medicine }\end{array}$ & $2(2.4)$ & $10(4.2)$ & 0.470 \\
\hline $\begin{array}{l}\text { Schizophrenic and delirious } \\
\text { patients }\end{array}$ & $6(7.3)$ & $18(7.5)$ & 0.940 \\
\hline $\begin{array}{l}\text { Affectiveness and Humor } \\
\text { disorders* }\end{array}$ & $54(65.1)$ & $114(47.5)$ & 0.006 \\
\hline Neurotic and Anxious & $21(25.3)$ & $84(35.0)$ & 0.100 \\
\hline $\begin{array}{l}\text { Retardation and Psychological } \\
\text { Development Disorder }\end{array}$ & $00(00)$ & $5(2.1)$ & \\
\hline
\end{tabular}

The nursing professionals had the highest register of appointments with an occupational therapist 19 (20.4\%), social assistant 26 (28\%), psychologists $20(21.5 \%)$ and psychiatrists 95 (100\%), however the differences were not statistically significant, with these respective $\mathrm{p}$ values: 0.68 ; $0.21 ; 0.52$ and 0.57 . This is the opposite of what was observed regarding the registers of appointments with nursing professionals, with a lower number of appointments by the workers by their own category $90(31.4 \%)$ compared to others $18(19.4)$; $p$ value 0.02 .

Among the nursing workers the female gender predominated 89 (95.7\%) and with prescription of controlled medication 90 (96.8\%). Such differences were statistically significant regarding to the other workers ( $p$ value 0.00 e 0.04 ).

Table 5 - Federal university nursing workers according to clinical characteristics

\begin{tabular}{|c|c|c|c|}
\hline \multirow[b]{2}{*}{ Characteristics } & \multicolumn{2}{|c|}{ Nursing professional } & \multirow[b]{2}{*}{ p value } \\
\hline & $\begin{array}{l}\text { Yes } \\
n(\%)\end{array}$ & $\begin{array}{c}\text { No } \\
n(\%)\end{array}$ & \\
\hline $\begin{array}{l}\text { Gender* } \\
\text { Female } \\
\text { Male }\end{array}$ & $\begin{array}{r}89(95.7) \\
4(4.3)\end{array}$ & $\begin{array}{l}182(62.3) \\
110(37.7)\end{array}$ & 0.00 \\
\hline $\begin{array}{l}\text { Nursing appointment* } \\
\text { Yes } \\
\text { No }\end{array}$ & $\begin{array}{l}18 \\
75\end{array}\left(\begin{array}{l}19.4) \\
80.6\end{array}\right)$ & $\begin{array}{l}90(31.4) \\
197(68.6)\end{array}$ & 0.020 \\
\hline $\begin{array}{l}\text { Appointment with Social Service } \\
\text { Yes } \\
\text { No } \\
\text { Appointment with Occupational }\end{array}$ & $\begin{array}{l}26(28.0) \\
67(72.0)\end{array}$ & $\begin{array}{r}62(21.6) \\
225(78.4)\end{array}$ & 0.210 \\
\hline $\begin{array}{l}\text { Therapist } \\
\text { Yes } \\
\text { No }\end{array}$ & $\begin{array}{l}19(20.4) \\
74(79.6)\end{array}$ & $\begin{array}{l}53(18.5) \\
233(81.5)\end{array}$ & 0.680 \\
\hline $\begin{array}{l}\text { Appointment with Psychologist } \\
\text { Yes } \\
\text { No }\end{array}$ & $\begin{array}{l}20 \\
73\end{array}\left\{\begin{array}{l}21.5 \\
78.5\end{array}\right)$ & $\begin{array}{r}53(18.5) \\
234(81.5)\end{array}$ & 0.520 \\
\hline $\begin{array}{l}\text { Appointment with Psychiatrist } \\
\text { Yes }\end{array}$ & $\begin{array}{c}95(100) \\
00(00)\end{array}$ & $\begin{array}{c}286(99.7) \\
1(0.6)\end{array}$ & 0.570 \\
\hline $\begin{array}{l}\text { Use of controlled medicine* } \\
\text { Yes } \\
\text { No }\end{array}$ & 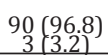 & $\begin{array}{l}257(89.9) \\
29(10.1)\end{array}$ & 0.040 \\
\hline
\end{tabular}




\section{Discussion}

The results of the study showed that although they are younger, the nursing professionals present a higher frequency of leaves due to mental health problems compared to the other categories investigated and they are kept away from work more days. Psychic problems can result as consequence of the unbalance between the demands which the work requires and the capacity of the worker to administrate the conflicts and adapt himself ${ }^{(10-11)}$. Psychosocial factors of the nursing professional are outstanding due to the high rate of related absenteeism ${ }^{(11,7)}$. The findings are similar to what was observed in other studies with public workers on the theme ${ }^{(12,10)}$, which implies in financial charges for the services of health, besides jeopardizing aspects of the social and family life of the patients suffering mental disorders.

The current configuration of the health services is based on management which does not consider the organization of the work as collective areas to learn and share, and so, they produce routine workers and users, fragmented, with low autonomy and little satisfaction $^{(13)}$. The high demand at work and low control, have been associated to the self-evaluation of negative health among the nursing professionals which contributes to the increase of dissatisfaction and stress ${ }^{(12)}$.

The lower the autonomy of the worker in the organization of his activity and bureaucratization is, the higher the chances of activity to generate mental disorders are ${ }^{(14)}$. The nursing professionals, who are responsible for most of the work force in the health institutions, despite being the main responsible for the care, have low prestige and social recognition ${ }^{(15)}$, reduced professional autonomy and so frequently suffers with the exposition to inadequate conditions and insalubrities at work ${ }^{(16)}$. Studies have shown that problems of behavioral and mental health are among the main causes of keeping these professionals away from work ${ }^{(6-7)}$.

Among the investigated professionals, inde- pendently of their functional category, there is a predominance of workers with medical prescription for use of controlled medication, which must have contributed for a higher demand of appointments with a psychiatrist. It should be highlighted that the assistance by the multiprofessional team in health is essential for the reception and support to the workers with problems of mental health ${ }^{(17)}$, however it is still necessary to be aware that it is possible to reach better results in the treatment of mental problem, when the care is not restricted to therapy with medicine.

To render complete care in mental health it is essential to have a multiprofessional team acting together and articulating themselves to answer the needs of health of the patients and increase the possibility of control, once isolated the therapy with medicine with a psychiatrist or alternatives with the other workers in the mental health area will produce less effective results than the several therapies together ${ }^{(17)}$. The investigated service has a multidisciplinary team in health, which allowed identifying that, for the nursing professionals, after the assistance with a psychiatrist the highest demand was the appointment with the social assistant. For the other categories, the second highest pursuit of appointments was with the nursing professionals with a significant statistic difference. There were no differences between nursing professionals and the other categories regarding the history of appointments with the psychiatry, social service, occupational therapy and psychology. This may be related to the search of health treatment in the complementary system to provide support to the problem of mental health. The federal civil servants receive governmental grant for the assistance to health in the supplementary net $^{(9)}$.

Other studies, as well as the present investigation, have proved that humor and affection disorders constitute one of the main problems of mental health in civil servants of different professional categories, especially depression for its high prevalence, possibility of recurrence and chronicity, 
which may affect a considerable parcel of the population, independently of gender, age, professional category or ethnicity. This disorder has been shown as a problem of public health related to high social costs and risks of suicide $\mathrm{e}^{(1,13,18)}$.

\section{Conclusion}

The study delineated the profile of the nursing professionals in a federal university assisted by multiprofessional team in mental health. There were differences in the clinical, occupational and sociodemographic characteristics of those compared to the other investigated workers, it was also highlighted a higher frequency of diagnosis of humor disorders, prescription of controlled medication and the pursuit for assistance of the multiprofessional team. Besides that, the nursing professionals keep away from their jobs longer and in a higher frequency than the other workers, due to problems of mental health, which represents a higher complexity and proportion of mental health problems in this population, with negative repercussions in their labor capacity.

However it is important to highlight that the study made presents some limitations, resulting from the fact that it is based on preexisting data, already registered in the medical records of the workers assisted in the medical services of the university. That is, it is not possible to state whether the professional category is determinant in the situation found among the nursing professionals. The conclusion cannot establish the temporality of the relation between the problems of mental health, keeping away from work and the professional category of the subjects.

Another limitation to be considered comes from the quality of information of the system studied, among them there might have occurred: difficulty in the reading of the information in the medical record due to the hand writing and the absence of data of interest, nevertheless, to minimize the possible faults, besides the training of the typists, the revision of the data bank and medical records was made in the pursuit of faults to be corrected.

\section{Collaborations}

Araújo GS contributed for the conduction of the study, data analysis and writing. Sampaio AS contributed in the project of study, data analysis and writing. Santos EA contributed in the construction of the project of study, data analysis and writing. Barreto SMG and Almeida NJV contributed in the construction of the project of the study, conduction of the study, data analysis and writing. Santos MLD contributed in the construction and conduction of the study.

\section{References}

1. Druck G, Seligmann-Silva E. As novas relações de trabalho, o desgaste mental do trabalhador e os transtornos mentais no trabalho precarizado. Rev Bras Saúde Ocup. 2010; 35(122):229-48.

2. Ministério da Saúde (BR). Organização PanAmericana da Saúde no Brasil. Doenças relacionadas ao trabalho: manual de procedimentos para os serviços de saúde. Brasília: Ministério da Saúde; 2001.

3. Elias MA, Navarro VL. A relação entre o trabalho, a saúde e as condições de vida: negatividade e positividade no trabalho das profissionais de enfermagem de um hospital escola. Rev LatinoAm Enfermagem. 2006; 14(4):517-25.

4. Ferreira LRC, De Martino MMF. O estresse do enfermeiro: análise das publicações sobre o tema. Rev Ciênc Méd. 2012; 15(3):243-8.

5. Chang A-K, Park J, Sok SR. Relationships among self-efficacy, depression, life satisfaction, and adaptation among older korean adults residing in for-profit professional nursing facilities. J Nurs Res. 2013; 21(3):162-9.

6. Mauro MYC, Paz A, Mauro CCC, Pinheiro M, Silva VG. Condições de trabalho da enfermagem nas enfermarias de um hospital universitário. Esc Anna Nery. 2010; 14(2):244-52.

7. Martinato MCNB, Severo DF, Marchand EAA, Siqueira HCHd. Absenteismo na enfermagem: uma revisão integrativa. Rev Gaúcha Enferm. 2010; 31:160-6.

8. Sá-Silva JR, Almeida CD, Guindani JF. Pesquisa 
documental: pistas teóricas e metodológicas. Rev Bras Hist Ciênc Soc. 2009; 1(1):1-15.

9. Brasil. Decreto no 6.833, de 29 de abril de 2009. Institui o Subsistema Integrado de Atenção à Saúde do Servidor Público Federal - SIASS e o Comitê Gestor de Atenção à Saúde do Servidor. Brasília: Presidência da República; 2009.

10. Ezaias GM, Haddad MCL, Vannuchi MTO. Manisfestações psico-comportamentais do burnout em trabalhadores de um hospital de média complexidade. Rev Rene. 2012; 13(1):1925.

11. Manetti ML, Marziale MHP, Robazzi MLCC. Revisando os fatores psicossociais do trabalho de enfermagem. Rev Rene. 2012; 9(1):111-99.

12. Theme Filha MM, Costa MAS, Guilam MCR. Occupational stress and self-rated health among nurses. Rev Latino-Am Enfermagem. 2013; 21(1):475-83.

13. Pereira MJB, Fortuna CM, Mishima SM, Almeida MCP, Matumoto S. Nursing in Brazil in the context of the work force of the health: profile and legislation. Rev Bras Enferm. 2009; 62(5):771-7.

14. Paparelli R, Sato L, Oliveira F. A Saúde Mental relacionada ao trabalho e os desafios aos profissionais da saúde. Rev Bras Saúde Ocup. 2011; 36(123):118-27.

15. Lu H, Barriball KL, Zhang X, While AE. Job satisfaction among hospital nurses revisited: a systematic review. Int J Nurs Stud. 2012; 49(8):1017-38.

16. Nelson S. A imagem da enfermeira - as origens históricas da invisibilidade na enfermagem. Texto Contexto Enferm. 2011; 20(2):223-4.

17. Meirelles MCP, Kantorski LP, Hypolito ÁM. Reflexões sobre a interdisciplinaridade no processo de trabalho de Centros de Atenção Psicossocial. Rev Enferm UFSM. 2011; 1(2):282-9.

18. Jardim S. Depressão e trabalho: ruptura de laço social. Rev Bras Saúde Ocup. 2011; 36(123):8492. 